\title{
Cultural codes of ancient cults in Chinese and Kazakh phraseology
}

\author{
Fatimabibi N. Daulet - Saule Anuar - Farida Orazakynkyzy - Aida A. \\ Kenzhebayeva - Rauan O. Dossymbekova
}

DOI: 10.18355/XL.2018.11.02.47

\begin{abstract}
The article examines of phraseological units (PU) with cult components in the Chinese and Kazakh languages. The article is relevant because of the attempt to fill the gap in comparative linguistic studies of PUs in the Chinese and Kazakh languages in general and cult concepts in particular. Cross-linguistic comparison of Chinese and Kazakh phraseology suggests that cultural codes represent and shape the worldview and mentality of groups of people. The purpose of the study is to identify typological similarities and ethno-cultural specificity of PUs with cult components in the Chinese and Kazakh languages. The material of the study consists of 3,000 PUs with cult components in the Chinese and Kazakh languages. The author applies comparative structural, typological, historical and etymological methods to produce a scientifically novel study of PUs with cult components in the Chinese and Kazakh languages. The study describes structural, semantic and thematic groups of PUs with cult components in the Chinese and Kazakh languages to discern national and universal cultural codes. The article has theoretical significance for the study of cultural codes and their representation in Chinese and Kazakh linguistic systems.
\end{abstract}

Key words: Chinese language, Kazakh language, linguistic worldview, spiritual cultural code, worship, cult, linguocultural studies

\section{Introduction}

According to V.A. Maslova (2001), phraseology not only reproduces the linguistic elements and features of national culture and mentality, but also shapes them. Embedded with cultural codes, phraseology makes up the mosaic of national culture. Phraseological units (PU) implicitly and explicitly convey cultural references about the world and society. Therefore, phraseology is a "treasure of wisdom" preserving national mentality and passing cultural codes from generation to generation.

The comparative study of PUs with cult components in the Chinese and Kazakh languages contributes to cognitive studies of the Chinese and Kazakh culture by approaching phraseology as one of the basic elements in the "mosaic worldview" of national culture. The article combines several approaches including methods borrowed from cultural and cognitive linguistics. PUs with cult components demonstrate the commonality and specificity of spiritual cultures and designate phraseology as an important marker of national mentality and taxonomy. Under the pressure of globalization, spiritual culture faces new moral and ethical challenges and undergoes significant changes that take place at the deep cognitive level of consciousness structuring new moral and ethical codes. Therefore, the study of traditional cultural and linguistic codes of spirituality is of particular interest because it reveals linguistic cognitive standards and stereotypes within the framework of Chinese and Kazakh linguocultures.

\section{Research Methodology}

The research is based on the foundational works in the field of comparative phraseology. The objectives of the study predetermined its methodology that combined lexico-semantic and structural-grammatical analysis, component value analysis of linguistic units, comparative analysis, as well as typological, historical, 
etymological methods of analysis. The following scientific works on phraseology made up the foundation for the study: V.N. Teliya (1996, 2005, 2008, 2010), V.I. Karasik (2004, 2009, 2010, 2013), M.L. Kovshova (2013), T. Aoshuan (2004), V.A. Maslova (2001), A. Wierzbicka (1985, 1992, 1996, 1997), F.N. Daulet (1999, 2017a, 2017b, 2018).

\section{Results and Discussion}

The comprehensive comparative analysis of PUs with cult components in the Chinese and Kazakh languages produced the following results:

1) Comparative and contrastive historical analysis makes it possible to examine the latent linguistic cultural layers of PUs;

2) PUs with cult components in the Chinese and Kazakh languages are determined by specific national conceptospheres;

3) The universal cultural code of spirituality is presented as a linguistic and philosophical category in the conceptual systems of the Chinese and Kazakh languages;

4) The comparative analysis of PUs with cult components can help differentiate the features of the national and ethnic worldview as well as identify common and specific features in the compared ethnocultures and languages;

5) The presence of PUs with cult components in both languages with desacralized cult components can be viewed as evidence of the semantic shift. In the course of historical development, PUs developed, changed and reinterpreted the references to cult components proving that phraseological imagery depends on the latent linguocultural components;

6) Semantic universals can be found in unrelated and non-contact languages, such as Chinese and Kazakh. The universal patterns of human thinking and the development of human civilization explain the presence of cultural-linguistic universals in these languages.

7) Cultural and linguistic specific features arise in the process of development of a particular language reflecting specific models of being and cognitive models adopted by one or another linguistic group;

8) National mentality includes collective values, systemized knowledge, worldviews, and concepts, viewed through the prism of social and emotional experience.

\subsection{Cult and its reflection in phraseology of the Chinese and Kazakh Languages}

The comparative analysis of PUs of the Chinese and Kazakh languages confirms once again that each nation creates its own unique worldview. The language stores and preserves the cultural and spiritual information of the people to pass it on from one generation to another.

Both the Chinese and Kazakh languages have a large number of PUs with cult components that bear reference to ancient mythological beliefs. To present, PUs with cult components remained stable lexical units and form the basis of ethnocultural and national heritage and wisdom.

The term "cult" comes from the Latin "cultus," which refers to the act of cultivating (colere), first in the literal agrarian sense, later in the figurative sense (to take care, to mind). It also means to worship and venerate divine. During the formation of the patriarchal-clan system the Chinese and Kazakh people worshiped celestial bodies, the blue sky, the dead ancestors and various totemic animals. The cult objects of worship were determined by many factors including the natural environment, history and materiality of culture.

China is famous for its rich ancient history and philosophy. Traditionally, Chinese historiography classifies three periods of the Han civilization: pre-imperial China (Xia, Shang, Zhou - until 221 BC); imperial China (Qin-Qing); new China (1911 modern). As early as XVIII-XII BCE, the state of Shan-Yin established the slave- 
owning system as a form of management (Ancient Chinese philosophy, p. 5). The slave labor was used in cattle breeding, farming, agriculture, and construction.

The cult-mythological worldview prevailed in the spiritual life of the Chinese people during the Shan-Yin period and during the initial stage of the Zhou dynasty. Zoomorphic gods were worshiped as the patrons and fathers of the Chinese people. For example, the goddess Nyuva was worshiped as a creator of mankind, a protector from floods and a patron of matchmaking and marriage. Nyuva had human head and hands and the body of a snake while Nyuva's husband Fusi Fu had a dragon's body (龙 ) with a human head (Yu-Lan, 1998).

Kazakh mythology assigned special importance to the Sky god - Tengri and the earth goddess - Umai, who was the ancient female deity of the Turkic peoples and patroness of children. The god of the underworld Erlik was depicted as an old man with horns (Ancient History of the Kazakhs, p. 342).

It is worth attention that the Chinese people also worshiped the Sky god 上帝 [shàng di] - Shang-Di "a supreme god of the sky." The ancient Chinese believed that ShangDi ruled over all other gods and spirits who obeyed his power. Shang-Di was the main deity presiding over the gods of the sky, rain, clouds, lightning, etc. Shang-Di was worshiped with animal and human sacrifices to win his favor and ensure his assistance. In Chinese phraseology the component Shang-Di is present in the PU 上帝 $\Phi$ [shàng dì băo yòu] - "Shang-Di, have mercy!" lit. mean.: "God forbid"; "God save." The Kazakh language has similar PUs to express good wishes: Kudai saktasyn - "Upasi Kudai" (God forbid), Tanir zhar bolsyn - "may Tengri keep you safe" (cf. Russian: “да хранит тебя господь Бог” - God bless you), Alla zhar bolsyn - "may Allah protect", etc.

In VI-V BCE, Shang-Di transforms into Tian-Di 天帝 [tiān dì] - "heavenly deity", where Heaven 天 [tiān] is worshiped as the creator and ruler of the world. The collections of folk songs "Shi Ching" and writings "Shu Jing" reflect the reverence towards the Sky as the divine being in VI BCE. The written records also describe the emperors and rulers as the sons of the Sky and executors of the divine will. For example: "The Sky is watching over the common people. The Sky is fair. The wealth or scarcity of the harvest depends only on the will of the Sky. The people cannot live without the Sky. The fate depends on the Sky" (Gumilyov, 2004). For ancient Chinese people, the Sky god was the benefactor of the people, the ruler of the universe, the ruler of natural forces, so the Celestial Empire had to obey the Sky (ibid, p. 47). At first, 天下 [tiān xia] - "the Celestial Empire" meant the whole world, and later denoted the territory under the rule of the Chinese emperor.

The cult of the Sky in the religious and mythological consciousness of the Chinese people is depicted in the following PUs: 天不假 年 [bù jiă nián] - "Sky (Heaven) did not give a long life," lit. mean. "short life"; 天 不怕, 地 不怕 [tiān bù pà, dì bù pà] "not to be afraid of heaven or earth," lit. mean. "nothing in the world is to be feared; to not know fear"; 天长地久 [tiān cháng dì jiǔ] - "as high as the sky and as permanent as the earth" lit. mean. "eternal”, “forever”; 天 从 人愿 [tiān cóng rén yuàn] - "Heaven provides everything that a person wants", lit. mean. "the god always helps men:; 天无绝人之之 [tiān wú jué rén zhī lù] - "The sky does not close the way for man", lit. mean.: there are no hopeless situations, etc.

According to K.K. Rysbayeva (1995, pp. 10-50), in the Kazakh language the lexicosemantic characteristics of PUs with the components $к ө \kappa$ (lit. the blue sky as the supreme lord), aspan (sky), tangir (Tengri), Kudai (the supreme deity) go back to shamanism, an early form of religion closely associated with magic, animism, fetishism, and totemism.

XLinguae, Volume 11, Issue 2, April 2018, ISSN 1337-8384, eISSN 2453-711X 
Worship of the sky is the main component in shamanism: "Shamanism is, on the one hand, the deification of nature in general and its phenomena in particular. Man worshiped nature as a material culture. But after death, according spiritual beliefs, man became Tengri" (Ualikhanov, 1985).

L.N. Gumilyov referred to the ancient Turkic tribes as "Tyurkuty" (Gumilyov, 2004) and wrote about their worship and veneration of the blue sky. There are also records of such veneration in the Chinese annals 魏书 - "Weishu" (History of the Wei

Dynasty), 隋 书 "Suishu" (History of the Sui Dynasty). According to L.N. Gumilyov (2004), the sky-venerating traditions included: "1) the entrance to Khan's headquarters was on the east in reverence to the sun;2) annual sacrifice rituals to honor ancestors; 3 ) in the middle of the fifth month, sacrifice in honor of the sky at the river; 4) the mountain to the west of Dugin is called Bodyn-inli, meaning the patron of the country" (2004 p. 73).

The cult of the sky - Tengri - is also recorded in Orkhon: "In the beginning there was a blue sky above and a dark earth below. They produced the sons of man." L.N. Gumilyov emphasized that Kok-Tengri (blue sky) is not material but spiritual and divine (Gumilyov, 2004, p. 75). He also wrote "... the worship of "the spirit of the Sky" continued until the beginning of the 20th century, although it underwent a considerable metamorphosis. The spirit of the sky received the Persian name Kudai (god) ..." (Gumilyov, 2004, p. 76).

The vocabulary of the modern Kazakh language in general and phraseology in particular abounds with examples that date back to the ancient Turkic cult of the sky Kok or Kok Tangiri. Later Islamic influence on Kazakh steppe culture transformed the sky deity into Persian Kudai, Arabic Alla or Allah. For example: Kok sokkyrmay the sky hit you (curse), Kudai kalasa - if allowed by Kudai, Alla zhar bolsa - if Allah helps.

It is noteworthy that in the Chinese and Kazakh languages PUs with the "sky" component refer to the divine ruler and have both positive and negative connotations. For example, kokke bagu ("ask the sky"), mean. to beg, ask; tobesi kokke zhetu ("the top reached the skies"), mean. great joy; kokke koterdi - "raised to the skies", mean. respect; kokten suragany zherden tabyldy - "ask the sky, but find on the earth", mean. luck; kokke koterildi - "rise to the skies", mean. high social status or joy; kokten tusti - "fell from heaven", an ironic comment on arrogant behavior; Kudai abyroi berdi - "Kudai (Almighty) help preserve honor", mean. to be in difficult situation and come out with an unblemished honor; Kudai saktap kaldy - "saved by Kudai", mean. a solution to a dangerous situation; Kudai zharylakady - "with Kudai's mercy" - about an escape from dangerous situation; Kudai kalasa - "if there is Kudai's will " - about plans for the future; Kudai kalady - "by Kudai's will" about successful business; Kudaiy konak - "Kudai sends a guest" - about the unexpected guest; Koktegi zhuldyz- "the star in the sky" - about an unattainable dream; aspanyng ashyk bolsyn - "May your sky be clear" - "Wish you peaceful life"; tobenge bult ainalmasyn - "Wish you clear sky above your head," - a wish to have good life; Allah razy bolsyn "May Allah be pleased with you" - a gratitude (cf. Russian: cnacuбo); Alla buiyrsa - "if it is predestined by Allah" - about upcoming plans; Allaga shukir - "glory to Allah" - all is well (thanks to Allah). The negativity is present in the curses Kok atsyn! (May the sky strike you), Kok karine ushyra! (May the sky strike you), Aspany zherge zhabysyp kaldy (May the sky strike the earth), lit. to have misfortunes; Allanyng amanatyn beru - "go back to Allah" lit. to die; Allasyn anda, akbaryn munda aitkyzdy - "to say "Allah" there, and "great" here" lit. stupid, it does not make sense. The irony is present in aspannan tuskendei (fell from the sky) lit. a disoriented and lost person. Aspannyng tubi tusti literary means "the broken bottom of the sky" and refers to the incessant rain. Similarly, aspan ainalyp zherge tuskendei literary means "as if the sky had fallen to the ground" 
and refers to extremely hot weather. The impossible dream is figuratively conveyed in the saying Aspandagy aiga umtylu - "stretch out your hand to the moon in the sky." The saying Aspandy alakandai, zherdi tebingidei kylu - "turn sky into the palm and the earth into ground into tebingi" (tebingi means the leather lobe of the saddle), lit. to panic in vain (cf. Russian: делать из мухи слона - to make something out of nothing). The saying Kudaiyn umytu means "to forget about the existence of Kudai" and refers to human ingratitude.

Chinese PUs with the "sky" component can express both positive and negative meanings. The positive connotations are present in the following examples:

天从人愿 [tiān cóng rén yuàn] - "Heaven gives everything that man wants";

天公地道 [tiān gōng dì dào] - "according to the justice of heaven and earth";

天马行空 [tiān mă xíng kōng] - "the heavenly horse rides through the air." In Chinese

mythology, 天马 [tiān mă] means the horse of the heavenly lord and refers to "the flight of thought; a wealth of imagination; fantasy";

天衣无缝 [tiān yī wú fèng] - "heavenly clothes has no seams", lit. perfect, flawless, without flaws;

天府之国 [tiān fŭ zhī guó] - "the country is the Heavenly Palace", lit. a blessed land; a heavenly place, Sichuan province;

天 高 皇帝 远 [tiān gāo huáng dì yuăn] - "heaven is high, and emperor is far", lit. lands with no justice and fear;

天经地义 [tiān jīng dì yì] - "the law of heaven and the order of the earth", lit. the truth;

天伦之乐 [tiān lún zhī lè] - "the joys of the laws of heaven" of the sky, lit. family joy, family happiness;

天命有归 [tiān mìng yǒu guī] - "subject to the will of heaven", lit. according to the will of the sky;

天网恢恢, 疏而不漏 [tiān wăng huī huī, shū ér bù lòu] - "the celestial net is wide and big, no one escapes", lit. nobody escapes retribution; everyone will get what they deserve.

The following examples convey negative connotations:

天怒人怨 [tiān nù rén yuàn] - "heaven and people are angry" lit. a crime that causes general indignation;

天冠地屦 [tiān guān dì jù] - "heavenly tiara and rope shoes," lit. great difference;

天罗地网 [tiān luó dì wăng] - "heavenly snares and earthly nets," lit. problems everywhere;

天 无二日 [tiān wú èr rì] - "there are no two suns in heaven", lit. the state cannot have two rulers;

天公不作美 [tiān gōng bù zuò měi] - "the heavenly lord does not favor", lit. bad weather or accidents;

天不假年 [tiān bù jiă nián] - "the heavens did not give a long life", lit. a short life; 天愁 地 惨 [tiān chóu dì căn] - "the heaven and the earth are in sorrow", lit. extraordinary grief;

天打雷䢃 [tiān dă léi pī] - "strike of heavenly lightning", lit. punishment; retribution.

The comparative historical analysis demonstrates that in the Kazakh and Chinese languages PUs with the "sky" component employ the imagery of sacred deities as linguocultural implications. In this respect, Chinese and Kazakh phraseologies share many similarities demonstrated in the following examples: 
天之骄子 [tiān zhī jiāo ž̀] - "beloved son of heaven" - the darling of fate; the lucky one - Kudaidyng kenzhe ulyndai - "like the youngest son of God" (cf. Russian: баловень Судьбы - the favorite of Fate);

天打雷䢃 [tiān dǎ léi pī] - "the blow of heavenly lightning," lit. the punishment - Kok sokkyr - "May the sky strike you down"; Kudai tas tobengnen urgyr - "May Kudai strike your back"; Alla zhazangdy bergir - "May Allah punish you";

天壤之别 [tiān răng zhī bié] - as heaven and earth - zher men koktei aiyrmashylyk;

天从人愿 [tiān cóng rén yuàn] - "heaven provides everything people want" - Kudai kalady "Kudai, help me"; Allah zhar boldy - "Allah support me";

天崩地裂 [tiān bēng dì liè] - "the sky fell, the earth split" - span kak aiyrylgandai "as if the sky split in two."

The Kazakh and Chinese languages employ metaphorical transformations of the sacred imagery. Compare the following examples in Chinese:

天 无二日 [tiān wú èr rì] - "there are no two suns in the sky", lit. the state cannot have two rulers;

天之骄子 [tiān zhī jiāo ž̃] - "beloved son of heaven" - the darling of fate; the lucky one - Kudaidyng kenzhe ulyndai - "like the youngest son of God";

天罗地网 [tiān luó dì wăng] - "heavenly snares and earthly nets", lit. about problems everywhere;

天 高 皇帝 远 [tiān gāo huáng dì yuăn] - "heaven is high and emperor is far" lit. about lands with no justice and fear;

and in Kazakh:

Allanyng amanatyn beru - "to go back to Allah" - lit. to die;

Allasyn anda, akbaryn mynda aitkyzdy - "say "Allah" there, and "great" here" lit: stupid, it does not make sense.

aspannan tuskendei - "as if fell from the sky," iron. a confused man;

kudaiyn umytu - "forget about the existence of Kudai", lit. ingratitude.

The comparison demonstrates that the above-mentioned PUs employ the components referring to the sky, Heaven, Tengri, Allah, Kudai underlining the significance of the sky cult in ancient Chinese and Kazakh cultures. Many proverbs and sayings are still actively used in modern Chinese and Kazakh and many PUs preserve the sacred cultural code.

The above statement can be supported by the following examples:

天 不作美 [tiān bù zuò měi] - "Heaven does not favor", lit. bad weather,

天 不怕, 地不怕 [tiān bù pà, dì bù pà] - "not afraid of heaven or earth", lit. to know no fear;

ura berseng Kudai da oledi - "if you do not stop beating, even Kudai (God) will die," lit. if there is a desire to achieve something, nothing is impossible;

Kudai bolsang $d a$ - "even if you are God," lit. whoever you are.

The above-mentioned examples contain components that underwent the semantic shift and desacralization. However, ritualistic and cult linguocultural implications are still detectable in the interpretation of cult symbols in phraseology.

\subsection{Totemic Imagery in Phraseology and Culture}

Totemism is an ancient religious and social system. People believed in the kinship with the object of worship: different natural phenomena (wind, sun, rain, thunder, water), flora (trees, flowers) and fauna (bear, wolf) or its parts (the claws of an eagle, the feathers of an owl, a wolf's tooth). Animal totems are the most common ancient totems due to prevailing zoomorphism, theriomorphism and atropomorphism in the ancient cultures. 
In Chinese mythology, the totems 龙 [lóng] (dragon) and 凤凰 [fèng huáng] (phoenix) represent the ancestors of the Chinese people. The dragon ete elóng] is a very important symbol of the ethnic identity of the Chinese. No wonder that the Chinese refer to themselves as 龙的传人 [lóng de chuán rén] - "the descendants of the Dragon." As noted by V.M. Alekseev (2012, p. 231), the cult of the dragon has a connection with the numerous floods that hurt farmers. The severe floods that destroyed houses and crops and caused human casualties were deified in the image of the dragon. As a river deity, the dragon was worshiped and feared by the ancient Chinese people who practiced animal and human sacrifices. Over time, the image of the dragon transformed into the image of the "ancestor" of the Chinese people. According to V.M. Alekseev (2012, p. 232), the Chinese people worshiped the dragon in hope to please and tame the natural forces that bring floods. Later, the totem of the dragon became a symbol of the Emperor of the country. For example, 龙 衣 [lóng yī] - lit. "the dragon's attire" means the emperor's clothes; royal clothes; 龙 凤 [lóng fèng] - "the dragon and the phoenix", lit. the emperor and the empress (Oshanin, 1983, p. 363).

As a rule, most PUs with the totem component 龙 [long] (dragon) convey positive meanings. For example, 放 龙入海 [fàng lóng rù hăi] - "to let the dragon into the sea", lit.: to give the opportunity to develop talents; 龙生 龙 [lóng shēng lóng] "dragon bears dragon," lit.: a good father has a good son (cf. Kazakh: zhaksydan zhaksy tuady, atanyng zholyn kuady - "from a good man, good children are born who continue the work of their ancestors"); 龙生 凤 养 [lóng shēng fèng yăng] "born by a dragon and nursed by a phoenix," lit.: of noble origin (cf. Kazakh: tekti zherden shykkan - "of noble origin"); 龙生 九子 [lóng shēng jiǔ zǐ] - "the dragon has nine sons, all of them different in appearance and character", lit.: different brothers (cf. Kazakh: bir atadan ala da tuady, kula da tuady - "from one father different children are born"), etc.

In Chinese mythology, Fenghuang 凤凰 [fèng huáng] is a miraculous bird that embodies the feminine principle. The ancient Chinese believed that appearance of Fenghuang to people is a sign of the emperor's power or a foreteller of a significant event.

In 《淮南子》 - [Huái nán žl - "Huainan Tzu" - "The Treatise of the Wise Men of Huainani", a philosophical treatise written during the Western Han Dynasty (about 139 BC), the image of Phoenix is described in a following way: "羽嘉生飞龙, 飞龙 生凤皇, 凤皇生鸾鸟, 变生庶鸟鸟, 凡羽者生于庶鸟." - “Yu Jia (father of all birds) gave birth to Feilong (flying dragon), Feilong gave birth to Phoenix, Phoenix gave birth to Luan Nyao (mythical bird), Luan Nyao gave birth to all other birds."

Another writing source - 大 藏经 [dà zàng jīng] - "The Great Tibetan Canon" mentions that Phoenix is the son of Feilong: "嘉羽生 应龙. 应龙生 凤皇". Many Chinese PUs employ Phoenix in a positive meaning. For example, 凤阁 龙楼 [fèng gé lóng lóu] - "the abode of the phoenix and the house of the dragon", fig.: the residence of the sovereign; the imperial palace; 凤鸣 朝阳 [fèng míng zhāo yáng] "the phoenix sings to meet the morning sun," fig.: a happy omen;凤毛麟角 [fèng máo 
lín jiăo] - "a phoenix feather and a unicorn horn," fig.: a rare phenomenon or an object; an extraordinary person; 凤凰 来 仪 [fèng huáng lái yí] - "the appearance of a pair of phoenixes," fig.: a happy omen.

Only a limited number of PUs with a phoenix as a component have a negative meaning. "The Great Phraseological Dictionary of the Chinese Language" contains many examples of PUs with totemic imagery. For example, 凤凰 在笯 [fèng huáng zài nú] - "the phoenix bird is locked in a cage", lit.: not to be able to show one's talents; 凤毛鸡胆 [fèng máo jī dăn] - "have a phoenix feather, but have the cowardice of a hen", lit.: a man who looks scary but is a coward.

Unlike Chinese mythology that venerated dragons, the Kazakh mythology regarded aidahar (a dragon) as an evil demon with several heads. Similarly to Chinese, many Kazakh tales described the dragon in close connection with the water but in Kazakh tales dragons also live in mountain caves and gorges, remote islands and the underwater kingdoms. Both mythologies anthropomorphize dragons. For example, in the fairy tale "Aidahar" the dragon turns into a beautiful woman to marry a good man. One night a wife turns into a dragon and drinks all water from the lake. In the fairy tale "Argy Mergen" dragon bursts and causes rain. Kazakh phraseology emphasizes the negative connotations of the dragon as a symbol of evil, darkness and dungeons. For example: aidahardai yskyrsy - "whistle like a dragon" - get very angry; alty basty aidahar - "a six-headed dragon" - an evil and ferocious man.

The ancient Turkic peoples shared a cult of kok bori-the "blue wolf", while in Chinese writing sources the image of the "blue wolf" appeared in IX BC. For example, 汉书 [hàn shū] "Hanšu" (a historical chronicle of the Han dynasty from 260 $\mathrm{BC}$ to $20 \mathrm{AD}$ ) and 周 书 [zhōu shū] - "Zhoushu" (a historical chronicle of the Zhou dynasty 534-581 AD) describe: "The Turks are descendants of Huns. During the military battles with neighboring states, the entire Hun tribe was destroyed. There was only a ten-year-old boy. The she-wolf rescued the boy and fed him. The ruthless ruler of the victorious kingdom ordered the boy to be killed. The she-wolf took the boy to the north of the Khanate Koshu (modern Turpan). Together they gave birth to ten sons. Growing up, the boys began to communicate with the neighboring tribes. They got families and children. Their descendants were divided into several tribes. After several centuries the tribe of Zhu-zhuang conquered them. They settled in the south of the Alatau Mountains and excelled in in blacksmithing" (Gabithanuly, 1995).

In Kazakh Kokzhal bori "a wolfish wolf" means a large wolf and serves to characterize a brave person. For example, zhigitteri shetinen kokzhal bori eken - lit.: "their men are like wolves, grey, brave and fearless" (Phraseological Dictionary of the Kazakh Language, p. 267); Kaskyr zhurekti - lit: "with a wolf's heart," a brave and bold man; kaskyr da kas kylmaidy zholdasyna - "even a wolf does not do evil to his friend"; kaskyr aiel - "a she-wolf", lit.: a clever woman.

Despite the sacralization of the wolf in many cultures, Kazakh phraseology often employs it figuratively in PUs that carry a negative meaning and disapproval: Kaskyrsha zhalaktau - greedy as a wolf; Kaskyrsha talau - biting like a wolf; Kaskyrsha ulu - howling like a wolf. There are many more examples of Kazakh proverbs and sayings: asyrandy kaskyr dalaga karap ulidy - "the tamed wolf still howls to the steppe" (cf. Russian: сколько волка ни корми, всё равно в лес cмompum - once a wolf always a wolf); kaskyrdy surlygy ushin emes, urlygy ushin urady - "the wolf is beaten not because he is gray, but because he ate a sheep"; maldyng iesi bolsa, kaskyrdyng kudaiy bar - "If the cattle have a master, then the wolf has a god." Fear of wolves is metaphorically present in the euphemism kara kulak - "black ears". 
In the Chinese language, PUs with the component of 狼 [láng] (wolf) also reveal the predominance of negative meanings, which yields to the conclusion that the Chinese treated the animal as a dangerous predator. For example: 狼心 [láng xīn] - "wolf's heart", lit.: greedy; cruel; 狼心狗肺 [láng xīn gǒu fèi] - "wolf's heart and canine lungs", lit.: cruel, ferocious, inhuman, shameless; villain; 狼子野心 [láng zǐ yě xīn] "wolf has a wolf's heart", lit.: malicious, incorrigible, deceitful; 狼吞虎咽 [láng tūn hŭ yàn] - "bite like a wolf, devour like a tiger", lit.: greedily devour.

In the Chinese and Kazakh languages there is a separate subsystem of PUs with the "wolf" component reflecting the ancient cultural and historical codes. Figurative cult phraseology demonstrates the attitudes of Chinese and Kazakh mentality and expresses the axiological aspect. For example, in both languages, the wolf is an active component in phraseology. In Chinese, most of PUs with the "wolf" component have negative connotations, while in the Kazakh language there are many examples with positive, neutral, and negative connotations. Significantly, both languages employ the totemic imagery of the wolf as a criterion of physical and moral human qualities.

The totemic image of the raven is often found in many ancient mythologies. For example, the ancient Tibetans considered the raven to be a messenger between the gods and people. They believe that the raven's sounds could predict various positive and negative events. The Manchu people had a custom to mount a pillar with a cloth attached to the top in the middle of the courtyard. Chopped pork was placed on the top of the pillar. If ravens ate the meat, it was believed a good omen. If ravens did not touch the meat, it meant unhappiness and misfortunes.

When the Mongols heard the raven, they said: "Take away bad, bring good." The Mongols considered the raven to be a sacred good and evil bird.

According to the ancient Chinese legend, 三 足 乌 [sān zú wū] "a three-legged raven" lives on the sun while a rabbit lives on the moon. Another legend told about ten solar ravens that lived on ten suns. One day, all ten ravens flew together and the world caught fire. The archer Hou-I saved the world by killing nine ravens. This legend is recorded in 后羿射日 [hòu yì shè rì] - "Hou-I knocked down Nine Suns". Similarly, the expression 乌兔 [wū tù] - "a raven and a hare", fig.: the sun and the moon (GCKD, 2 vol., p. 507); 乌飞兔走 [wū fēi tù zǒu] - "the raven flies, the hare runs" fig.: "time flies".

The ancient Chinese believed that the crow cares about the elderly parents. The belief is implied in the PUs 乌鸟私情 [wū niaǒ sī qíng] - "feelings of a crow", fig.: respect for parents, veneration of parents; 爱屋及乌 [ài wū jí wū] - fig.: "to love the house, but also the crows on its roof", fig.: to love family, to love home.

The phraseology of the modern Kazakh language offers a wide variety of expressions with "a raven" as a component. For example, karganyng bir kozi okta, bir kozi bokta "the raven looks with one eye at the arrow, with another eye at the litter", fig.: a greedy person; karga karganyng kozin shukymas - "the raven does not turn down the raven"; karga adym zher - "with a crow's step"; karga boily - "height of a crow", fig.: short; karga tamyrly kazak - "the Kazakh has ravens as relatives", fig.: the Kazakh has relatives everywhere; karga tumsyk - "a crow's beak", fig.: a sharp nose; karga siakty karkyldau - "to croak like a crow", etc.

Both Chinese and Kazakh ancient mythologies assigned special significance to the sun. In the Kazakh language, the word for the sun is kun. In the Chinese language the hieroglyphs 日 [ri] or 阳[yang] refer to cosmic and astral deities as primary totems. Ancient cultures deified the sun and considered it to be the creator of the universe. The sun acquired totemic significance as the creator of human civilization.

XLinguae, Volume 11, Issue 2, April 2018, ISSN 1337-8384, eISSN 2453-711X 
The ancient Kazakhs also believed that the weather and natural disasters (draughts, storms, thunder, lightning, rain, hail) depend on the mood of powerful Sun (Rysbayeva, 1995). A. Konyratbayev (1987) writes: "The worship of the Sun is clearly seen in the stone monuments, put up by the Kipchaks in honor of their parents, fallen heroes, historical figures. All monuments face the east".

Ancient people worshiped the sun because they understood that life is impossible without sunlight. K. Gabithanuly (1995) noted that the ancient Huns considered themselves descendants of the sun. He developed a hypothesis about the relationship between the word $\kappa{ }^{\mu}$ (sun) and the name of the Hun tribe (in ancient Turkic кӥн - the sun).

The Chinese scientist S. Beihai (1989, p. 121) in his work 哈萨克族 文化史 [The History of Kazakh Culture] writes about the nomadic Saks: "Of all deities, they worshiped only the god of Sun. They sacrificed only horses. The choice of a horse as a sacrifice can be explained by the ancient Saks belief that only a fast horse could reach the sun".

Some scholars (Ch. Valikhanov and others) doubted that totem of the sun existed in ancient Kazakh culture but Kazakh phraseology suggests otherwise. For example, kun batty - "the sun went down" can be substituted with kun baiydy - lit. "the sun is rich"; kun koru - "to see the sun" - to live; kun bermeu - "to not give the sun" - to not give life; kuni karang - "the sun is dark" - problems in life; kopting korgrn kuni - "the sun sees everything" - lit.: god sees all people; kuni kun emes - "his sun is not the sun" - lit.: a bad person, and many others. Kazakh phraseology suggests that the sun was deified.

In the Chinese language, the sun is represented by 阳 [yáng] - “yang”, the positive (male) principle, a category that interacts with 阴 [yīn]- "yin", the negative (feminine) principle of the universe.

In the ancient Chinese fortune-teller book "Ijing" 易经 [yì jīng] ("The Book of Changes"), it is said that the world was created with the help of 阳 [yáng] - the sun the positive substance, 阴 [yīn] - the shadow from the sun - the negative substance and 水 [shuǐ] - water, 火 [huǒ] - fire, 木 [mù] - tree, 土 [tǔ] - earth, 金 [jīn] - metal.

In Chinese mythology, five deities acted as 太阳 神 [tài yang shén] - "gods of the sun": 羲 和 [xī hé] - the goddess Xihe, who gave birth to ten suns and harnessed dragons to her chariot; 东君 [dōng jūn ] - Dongjun, the Lord of the East, the deity of the sun; 神农 [shén nóng]-Shennong, the God farmer; 东皇 [dōng huáng] Dunhuang, the Lord of the East, the deity of spring and the deity of the sun; 炎帝 [yán dì] - Yan Di, the Flame Emperor, the lord of the south and the god of fire, sun and summer (Dictionary of Ancient Terms, p.187).

山海经 - "Shanghai Jiang" - "Book of Mountains and Seas" is the main source of knowledge about the myths of ancient China. It recorded the following legend: "Xihe rode a chariot drawn by six dragons and took one of the brothers - the suns - to the sky, while the rest had to sit on a tree and wait for their turn. That's why people thought that there was only one sun. In the end, the brothers got bored with such a monotonous life. They conspired and the next morning they flew to the sky after the chariot, scattered all over the sky and began to play. They ignored the mother's warning because they were not well behaved. They began to fly to the sky every morning together. The earth was scorched with heat, people turned black and famine came to their homes. Animals flew from the burning forests and boiling rivers, birds flew out, fish went to the shore. The ten suns played in the sky, without paying attention to misfortunes they cause to mankind. The modest wise emperor Yao, who lived in a simple reed hut and ate herbs, was very saddened by the misfortunes of his 
people. He respectfully asked the Supreme Lord of the East to restrain his children. The Lord sighed heavily and called for the celestial archer Yi. He ordered the archer to come down to the earth and frighten the naughty children so that they flew off to the Fusang tree themselves and took turns to play in the sky under the mother's supervision (Dictionary of the Ancients terms, p. 775).

The structural and semantic analysis of PUs with the "sun" component in the Chinese and Kazakh languages demonstrates that they share semantic and stylistic similarity, which is a rare case for unrelated and non-contact languages. For example, 日落西山 [rì luò xī shān] - "the sun sets over the western hills", fig.: to live out the last days; to die (cf. Kazakh: kuni bitti - “the sun extinguished"); 日暮途远 [rì mù tú yuăn] - "the sun goes down, and the path is still far", fig.: not to achieve a worthy position to the end of life (cf. Kazakh: kuni taiap kaldy - the sun is approaching the sunset); 日 日夜 夜 [rì rì yè yè] - "days and nights" - night and day; all day long; all the time (cf. Kazakh: kun demei, tun demei); 日薄西山 [rì bó xī shān] - "the sun sets over the western hills", lit.: to live out the last days (cf. Kazakh: kuni bitti - "the sun went down"; kuni sondi - "the sun went out"); 过日子 [guò rì zi] - "spend the days," lit.: to live; to age; to live long (cf. Kazakh: kun otkizu - "to spend sun days" - lit.: to spend days, to live; 日上三竿 [rì shàng sān gān] - "the sun is at the height of three poles", lit.: the sun is high; lunchtime (cf. Kazakh: kun arkan boiy koterildi - "the sun rose in the length of one rope" (a rope 4-5 meters long)"; 日升月恒 [rì shēng yuè héng] - "the rising sun, the growing moon," lit.: about continuous development, steady advance (cf. Kazakh: kun sanap osu); 日久 天长 [rì jiǔ tiān cháng] - "the day is eternal, the sky is long," lit.: during long time (cf. Kazakh: kunderding bir kuninde); 日就月将 [rì jiù yuè jiāng] - "to achieve success and progress every day and month", lit.: to progress (cf. Kazakh: kun sanap osu); 有 脚 阳春 [yǒu jiăo yáng chūn] - "a sunny spring on the living feet," lit.: a very kind person (cf. Kazakh: kun nuryndai meirimdi); 阳 关大道 [yáng guān dà dào] - "a great way for the Yangguan border", lit.: a light path; a wide path (cf. Kazakh: nurly zhol).

\section{Conclusions}

The comparative analysis of the cult imagery in PUs in the Chinese and Kazakh languages demonstrates similar patterns of reinterpretation and metaphorization of the sacred images. The comparative and contrastive historical analysis offers the key methods to examine and explore the latent linguistic cultural information embedded in phraseology. Many of the above-mentioned examples are still prevalent and actively used in modern Chinese and Kazakh indicating the presence of the ancient spiritual code in modern culture. Many of the PUs presented in the work have not lost their sacred meaning, and their cultural code has not been "wiped out".

Desacralization of the cult imagery in PUs occurred due to the cultural shift and the reinterpretation of phraseology based on the cult symbols. In the Chinese and Kazakh languages, the cult imagery in phraseology is preserved not only through the actualization of sacred images but also due to the actualization of implied meanings. The study proved that semantic universals could exist in unrelated and noncontact languages like Chinese and Kazakh. It is obvious that the presence of culturallinguistic universals in these languages is due to the universal character of human thinking, the common patterns in historical development and the universality of consciousness.

Cultural-linguistic particularity is a result of the process of the linguistic representation of reality that reflects specific existential and cognitive models adopted by linguistic community. It is shaped by the historical and socio-psychological

XLinguae, Volume 11, Issue 2, April 2018, ISSN 1337-8384, eISSN 2453-711X 
characteristics of the linguistic group. Thus, national or ethnic mentality includes collective values, systemized knowledge, and worldview concepts viewed through the prism of social and emotional experience.

\author{
Abbreviations: \\ mean. - meaning \\ etc. - so on and so forth \\ iron. - ironic \\ fig. - figurative meaning \\ lit. - literal meaning \\ cf. Russian - compare with Russian \\ cf. Kazakh - compare with Kazakh \\ PU - phraseological unit
}

\title{
Bibliographic references
}

ALEKSEEV, V.M. 2012. V starom Kitae. Dnevniki puteshestija 1907 goda. Moscow: Izdatelstvo Vostochnaya Literatura. ISBN 978-5-02-036518-6

ANCIENT HISTORY OF THE KAZAKHS. 1993. Almaty: Zhalyn. ISBN: 5-610-010 AOSHUAN, T. 2004. Kitayskaya kartina mira. YAzyk, kul'tura, mental'nost'. Moscow: YAzyki slavyanskoy kul'turyISBN 5-9551-0035-0

BEIHAI, S. 1989. The history of Kazakh culture. Urumqi: Publishing House of Xinjiang University.

DAULET, F.N. 1999. Sopostavitel'nyy analiz frazeologizmov kitayskogo i kazakhskogo yazykov: Doctoral dissertation. Almaty.

DAULET, F.N. 2017a. Sopostavitel'nyy analiz kul'turnykh kodov vo frazeologizmakh kitayskogo i kazakhskogo yazykov. Moscow: Triumf. ISBN 978-5-89392-775-7

DAULET, F.N. 2017b. Yazyk i simvoly kul'tury: sopostavitel'nyy analiz dialektov, inoyazychnykh zaimstvovanii, form obrashcheniy i kolorativnoy leksiki kitayskogo i kazakhskogo yazykov. Moscow: Triumf. ISBN 978-5-89392-777-1

DAULET, F.N. 2018. Yazykovaya kartina mira: strukturno-semanticheskiye i lingvokul'turologicheskiye kharakteristiki frazeologii kitayskogo i kazakhskogo yazykov. Moscow: Triumf.

DICTIONARY OF ANCIENT TERMS. 1998. Shanghai: Tseshu Chubanshy.

GABITHANULY, K. 1995. Ustoychivyye slovosochetaniya v kazakhskom yazyke, svyazannyye s narodnymi pover'yami.:Doctoral dissertation. Almaty.

GUMILYOV, L.N. 2004. Drevniye tyurki. Moscow: FTM. ISBN 5306003133

KARASIK, V.I. 2004. Yazykovoy krug: lichnost', kontsepty, diskurs. Moscow: Gnozis. ISBN 5-88234-552-2

KARASIK, V.I. 2009. Yazykovyye klyuchi. Moscow: Gnozis. ISBN 978-5-94244$030-5$

KARASIK, V.I. 2010. Yazykovaya kristallizatsiya smysla. Moscow: Gnozis. ISBN 978-5-94244-035-0

KARASIK, V.I. 2013. Yazykovaya matritsa kul'tury. Moscow: Gnozis. ISBN 978-594244-0433-5

KONYRATBAYEV, A. 1987. Kazakhskiy epos i tyurkologiya. Almaty: Gylym. ISBN 5-628-02202-0

KOVSHOVA, M.L. 2013. Lingvokul'turologicheskiy metod vo frazeologii: Kody kul'tury. Moscow: Librocom. ISBN 978-5-9710-2431-6

MASLOVA, V.A. 2001. Lingvokul'turologiya. Moscow: Akademia. ISBN 5-76950745-4

OSHANIN, I.M. 1983. Bolshoy Kitaysjo-Russkiy slovar' v 4 tomah. Moscow: Nauka. PHRASEOLOGICAL DICTIONARY OF THE KAZAKH LANGUAGE. 1977. Alma-Ata: Gylym. ISBN 5-628-02202-0 
RYSBAYEVA, K.K. 1995. Kul'tovyye frazeologizmy v kazakhskom yazyke: Doctoral dissertation. Almaty.

TELIYA, V.N. 1996. Russkaya frazeologiya. Semanticheskiy, pragmaticheskiy i lingvokul'turologicheskiy aspekty. Moscow: Shkola "Yazyki russkoy kul'tury". ISBN 5-88766-047-3

TELIYA, V.N. 2005. O fenomene vosproizvodimosti yazykovykh vyrazheniy. Moscow: MAX Press. ISBN 978-5-317-05488-5

TELIYA, V.N. 2008. Lingvokul'turologiya kak klyuch k novoy real'nosti fenomena vosproizvodimosti neskol'koslovnykh obrazovaniy. Moscow: Gnozis. ISBN 5-73330184-8.

TELIYA, V.N. 2010. Lingvokul'turologicheskaya gipoteza vosproizvodimosti yazykovykh vyrazheniy. Zhivoystvuyushchaya svyaz' yazyka i kul'tury. In: Proceedings of the conference dedicated to the anniversary of Professor V.N. Teliya. Tula, vol. 1, n. 1, 252-255.

UALIKHANOV, Sh. 1985. Izbrannye sociheniya. Almaty: Zhazushy. ISBN 5-60501755-1.

WIERZBICKA, A. 1985. Lexicography and Conceptual Analysis. Arbor: Karoma Publishers Inc. ISBN 9780897200691

WIERZBICKA, A. 1992. Semantics, Culture, and Cognition. Universal Human Concepts in Culture Specific Configurations. New York: Oxford University Press. ISBN 0195073266

WIERZBICKA, A. 1997. Understanding Cultures through Their Key Words: English, Russian, Polish, German and Japanese. Oxford: Oxford University Press. ISBN 0195088360

WIERZBICKA, A. 1996. Semantics: Primes and Universals. Oxford: Oxford University Press. ISBN 0198700024

YU-LAN, F. 1998. Kratkaya istoriya kitayskoy filosofii. St. Petersburg: Evraziya. ISBN 5-80710016-6.

Words: 7535

Characters: 44836 (24,91 standard pages)

Assoc. Prof. Fatimabibi Nogaikyzy Daulet, $\mathrm{PhD}$

Institute of Asian and African Countries

Moscow State University

11 Mokhovaya Str.

125009 Moscow,

Russia

fatima-dauletova@mail.ru

Assoc. Prof. Saule Anuar, PhD

International Kazakh-Chinese Language College,

45a, 5 microdistrict Str.

050062 Almaty

Kazakhstan,

Shw11966@sina.com

Assoc. Prof. Farida Orazakynkyzy, PhD

Abai Kazakh National Pedagogical University

13 Dostyk Str.

050010 Almaty

Kazakhstan

Faridak09@mail.ru

XLinguae, Volume 11, Issue 2, April 2018, ISSN 1337-8384, eISSN 2453-711X 
Assoc. Prof. Aida Abdyganievna Kenzhebayeva, PhD

Ablaikhan Kazakh University of International Relations and World Languages

200 Muratbaeva Str.

050022 Almaty,

Kazakhstan

kazumo@ablaikhan.kz

Senior Lecturer Rauan Orikbayevna Dossymbekova, $\mathrm{PhD}$

Al-Farabi Kazakh National University

71 Al-Farabi Ave.

050040 Almaty

Kazakhstan

info@kaznu.kz 